\title{
Relationship between Sports Habits and Physical Activity to Blood Pressure in Hypertension Patients in Puskesmas Siliwangi
}

\author{
Nina Sumarni, Mamat Lukman, and Citra Windani Mambang Sari* \\ Faculty of Nursing, Universitas Padjadjaran \\ Correspondency e-mail: citra.windani@unpad.ac.id \\ Type of the Paper (Article) \\ Received: May 21, 2019; Accepted: August 06, 2019; Published: August 12, 2019 \\ https://doi.org/10.29253/achnr.2019.12019
}

\begin{abstract}
Hypertension is a disease due to lifestyle. Sports and physical activity is one of the things that can affect hypertension. The aim of the study was to identify the relationship between exercise and physical activity against blood pressure in hypertensive patients in the Muara Sanding Village of Garut. This type of research is descriptive correlative with a population of all hypertension patients who active in Prolanis activities that held once a week in the Muara Sanding village, Garut. The sampling technique is total hypertension patients as much 51 respondents. The instrument used is a questionnaire about exercise and physical activity and assessment of blood pressure. The analysis used bivariate. Most respondents did moderate activities (67\%), and a small number did less exercise (37\%). There is a significant relationship between blood pressure and exercise ( $p$-value $=0.02)$, but there is no significant relationship between blood pressure and physical activity ( $p$-value $=0,38$ ). Suggestions from this study are nurses providing health education about the importance of exercise and improving exercise habits in hypertension patients.
\end{abstract}

Keywords: hypertension; physical activity; sport

\section{Introduction}

Increasing economic capacity has an impact on changing healthy lifestyles to become unhealthy, over time, various types of diseases appear that are associated with unhealthy lifestyles. This disease will be an obstacle to efforts to improve the degree of public health and the increasing cost of treatment needed (Ministry of Health, 2012). Increased blood circulation disease is the impact of an unhealthy lifestyle. One common type of blood circulation disease is hypertension because hypertension can cause strokes and congestive heart failure. According to the WHO in 2013, there were at least 972 million cases of hypertension, estimated in 2025 cases of hypertension to be 1.15 billion or $29 \%$ of the total population in the entire world who suffer from hypertension (Ardiansyah, 2012).

In Indonesia, hypertensives $95 \%$ of cases of unknown cause (MoH RI, 2014). The number of hypertensive patients who underwent outpatient hospital throughout Indonesia is on the second of the ten most prevalent diseases. Based on data from Garut Health Profile 2015, the number of hypertensive patients as many as 20198 cases, and an increase in 2016 be 71 776. The number of ranks 3 of 10 biggest disease that previously was ranked fifth. 
According to Triyanto (2014), hypertension does not have specific symptoms, but there are several indicators that can be used as guidelines including dizziness, headache, severe neck pain, restlessness, redness, stiffness, emotion, wheezing, sleeplessness, difficulty breathing, easy weakness, disorders of the eyes, due to damage that occurs in the brain, heart, and kidneys. Almost most patients with high blood pressure have unhealthy and bad habits, including smoking, frequent stress, lack of activity, like to drink coffee, have a history of cholesterol, eat fatty foods, high salt intake, and excessive body weight, this behavior is a stimulant of the common causes of hypertension that occur a lot. High blood pressure can control by taking a diet, taking medication, and regular exercise.

Physical activity refers to activation of skeletal muscle and leads to movement and increased energy expenditure (Cartee et al, 2016). When a person is exercising heavily, the systolic blood pressure can rise 150-200mmHg, which at rest 110-120mmHg. Once the exercise is complete, the blood pressure will drop below normal and last between half an hour to two hours. Decreased blood pressure results from dilation of blood vessels and relaxation (Levine, 2001). Running, swimming, and cycling will stimulate contractions of large muscles so that they affect the cardiovascular system, increasing systolic, diastolic, and arterial blood pressure. During sports activities, the physiological response of the cardiovascular system is to increase the heart rate so that the amount of blood that can be distributed becomes more quickly received by blood cells flowing rapidly through the blood vessels. Through exercise, the muscles become trained, adequate metabolism has an impact on the smooth circulation of blood containing oxygen in the body. Regular exercise activities can burn bad cholesterol in the body and can increase good cholesterol levels.

Everyone recommends sports, both healthy people who are on a diet, and people who are unhealthy are strived to keep doing light exercise because exercise can maintain body health. Through sports activities, the body is healthy and prevents the risk of hypertension, stroke, being overweight, and heart disease. Regular body movements accompanied by a healthy lifestyle include maintaining nutritional intake, not smoking, and getting enough rest. The results of the study Surbakt (2014), walking exercise for half an hour (30 minutes) in a day was able to reduce systolic and diastolic blood pressure in patients with high blood pressure at Kabanjahe General Hospital. Likewise, the results of Libriyanti's study (2016), there is a significant relationship between the incidence of hypertension and exercise, which is $p=0.001$ with $\alpha=0.05$. While the results of Gilang's research (2014), there were differences in blood pressure after and before healthy heart gymnastics in hypertensive patients in Mojoranu Village, Dander District, Bojonegoro Regency. According to the study conducted by Glenn Gaesser, director of Arizona State University's Healthy Lifestyles Research Center (2012), reported that low exercise is very good for people with hypertension. In his study, Gaesser found that moderate exercise divided into three parts in one day, such as three times walking for 10 minutes, can prevent spikes in blood pressure compared to one walk for 30 minutes. Whereas according to Dr. Rossana Barack, Chair of the Indonesian Society of Hypertension, is recommended for hypertensive patients to do cardiovascular exercise such as jogging or treadmill for at least 150 minutes per week. The aim of the study was to identify the relationship between exercise and physical activity against blood pressure in hypertensive patients in the Muara Sanding Village of Garut.

\section{Methods}

This type of research is descriptive correlative which identifies whether or not there is a relationship between physical activity and exercise against blood pressure. The population in this study was hypertension patients who were active in Prolanis gymnastics activities held once a week in the Muara Sanding village located in the Siliwangi Garut Health Center work area. The sample is a total sampling of 51 respondents. The instrument used was a questionnaire made by author by the type of closed questionnaire, check, and the content validity test was carried out by experts. An instrument in the form of a questionnaire about physical activity and exercise carried out by patients. Blood pressure measurements using a single tool that has been calibrated sphygmomanometer. Data analysis using frequency distribution and chi-square. This study has been approved by the research ethics commission of ethics Universitas Padjadjaran No. 1114 / UN6.KEP / EC / 2018. 


\section{Results}

Table 1 describes the characteristics of patient Hypertension in the village of Muara Sanding. Based on Table 1, almost all respondents (90\%) were women, a small portion of respondents (35\%) were aged 36-45 years, almost half (49\%) had a primary school educational background, and most are employees.

Table 1. Frequency Distribution of Respondent characteristics

\begin{tabular}{lll}
\hline Subvariabel & F & $\%$ \\
\hline Gender & 5 & 10 \\
Male & 46 & 90 \\
Female & & \\
Age & 6 & 12 \\
$26-35$ years old & 18 & 35 \\
$36-45$ years old & 12 & 23 \\
$46-55$ years old & 9 & 18 \\
56 -65 years old & 6 & 12 \\
$>65$ years old & & \\
Education & 22 & 43 \\
Elementary & 20 & 39 \\
Junior High & 9 & 18 \\
Senior High & & \\
Employment & 17 & 33 \\
Does not work & 25 & 49 \\
Employee & 6 & 12 \\
Small trader & 3 & 6 \\
Pension & & \\
\hline
\end{tabular}

Table 2 describes the physical activity of respondents. Based on table 2, half of the respondents $(67 \%)$ did moderate physical activity

Tabel 2. Physical Activity

\begin{tabular}{lll}
\hline Activity level & F & \% \\
\hline High & 5 & 10 \\
Moderate & 34 & 67 \\
Low & 12 & 23 \\
\hline
\end{tabular}

Table 3 describes the sport that made respondents. Based on Table 3, a small portion of respondents (37\%) did low exercise.

Table 3. Exercise

\begin{tabular}{lll}
\hline Level of Exercise & F & \% \\
\hline Good & 15 & 30 \\
Sufficient & 17 & 33 \\
Low & 19 & 37 \\
\hline
\end{tabular}

Table 4 illustrates the blood pressure of the respondents. Based on Table 4 , the majority of respondents' assessment results of blood pressure is above 140/90 mm $\mathrm{mg}$

Tabel 4. Blood Pressure

\begin{tabular}{cll}
\hline Variable & F & \% \\
\hline$>140 / 90 \mathrm{mmHg}$ & 28 & 55 \\
$<140 / 90 \mathrm{mmHg}$ & 23 & 45 \\
\hline
\end{tabular}


Table 5 illustrates the analysis of the relationship between physical activity and blood pressure. Based on table 5, there was no significant relationship between physical activity and blood pressure in the respondents.

Table 5. Analysis of activity level and blood pressure

\begin{tabular}{ccccc}
\hline $\begin{array}{c}\text { Variable } \\
\text { Blood pressure }\end{array}$ & Low & $\begin{array}{c}\text { Level of Activity } \\
\text { Moderate }\end{array}$ & High & P-value \\
\hline$>140 / 90 \mathrm{mmHg}$ & 2 & 18 & 3 & 0.38 \\
$<140 / 90 \mathrm{mmHg}$ & 10 & 16 & 2 & \\
\hline
\end{tabular}

Table 6 illustrates the analysis of the relationship between exercise and blood pressure. Based on table 6 , there is a significant relationship between exercise and blood pressure on respondents.

Table 6. Analysis of blood pressure and exercise

\begin{tabular}{ccccc}
\hline Variable & \multicolumn{2}{c}{ Exercise } & P-value \\
\cline { 1 - 4 } Blood pressure & Poor & Sufficient & Good & 0.02 \\
\hline$>140 / 90 \mathrm{mmHg}$ & 4 & 8 & 11 & \\
\hline $140 / 90 \mathrm{mmHg}$ & 15 & 9 & 4 & \\
\hline
\end{tabular}

Based on Table 5, can be known that the physical activity of most respondents was categorized as moderate activity, amounting to 34 respondents (67\%) with the controlled blood pressure of 18 respondents and uncontrolled blood pressure of 16 respondents. And the heavy activity categories were five respondents with three respondents with controlled blood pressure and whose blood pressure was uncontrolled as much as two respondents and the activity was as light as 12 respondents two people their blood pressure was under control and ten people had uncontrolled blood pressure. Results of Analysis of activity levels and blood pressure on respondents in the Muara Pengasan Village at the Siliwangi Community Health Center are Sig. $=0.038(\mathrm{a} \leq 0.05)$ means that H0 is rejected and accepts H1. Namely, there is a relationship between physical activity of exercise and blood pressure in people with hypertension in Muara Sanding Village, Siliwangi Community Health Center. The results of the analysis also found a negative correlation value that was proven by the correlation coefficient value of -0.292 , which means that the activity increases blood pressure decreases.

\section{Discussion}

The results of the analysis also found a negative correlation, which means that the activity increases blood pressure decreases. This is in line with the research conducted by Andriani (2017), there is a significant effect of physical activity of hypertension in early adult men with a value of $p=0.010 \mathrm{OR}=$ 3.095, early adult men who do light activities have a risk 3 times the chance of being exposed hypertension compared to those who have moderate and severe physical activity. Likewise with the results of Atun's research, et al. (2014) there was a significant relationship between physical activity and the incidence of hypertension, with a value of $\mathrm{OR}=4.69$, which means that people with mild physical activity had an opportunity or risk of 4.69 times suffering from hypertension compared with those with moderate activity.

The results of Khomarun, et al. (2014) showed a significant change in which there was a decrease in systolic blood pressure on respondents after walking in the morning by 40 times in 8 weeks, as well as the results of a study by Budiono (2015). age in Naben Village, Mirit District, Kebumen Regency with $p=0.013(<0.05)$. The results of this study are in line with the research of Hasanudin (2018) that there is a relationship between physical activity and blood pressure in people with hypertension in the Tlogosuryo region, Tlogomas Village, Lowokwaru District, Malang City. According to research results by Librianti. P (2016) Physical activity is also called external activity, which is an activity that expends energy or energy in carrying out physical activities, for example, walking, running, and exercising. According to Giam (2000), Regular and regular physical activity is very good because help heart muscles 
and peripheral resistance so that it can stabilize blood pressure. Whereas according to Marliani (2007), the lack of physical activity makes the organs of the body and the blood supply and oxygen become stagnant, which increases blood pressure. Regular physical activity can make the heart muscle more efficient. Someone who is physically active has lower blood pressure and rarely suffers from high blood pressure; they tend to have better muscle function, joints, and organs that are stronger and more flexible - conversely, people whose physical activity lacks a heavier heart because of their heartbeats higher. The activity of the body causes an increase in energy by the body beyond the resting energy; the amount of energy needed depends on how heavy the work has done. Many factors affect hypertension. One of the factors that influence the incidence of hypertension is physical activity. Good and routine physical activity will train the heart muscle and peripheral resistance, which can prevent an increase in blood pressure. Based on the results of the study, almost all respondents do it very often, namely going to the fields almost most (farm laborers) and doing homework activities from the morning, evening and caring for grandchildren. A small part of respondent worked on cleaning the house, and those who carried out heavy activities with trade around the village carrying kerobak.

\section{Sports relationship with blood pressure}

The results of the analysis of the relationship between exercise and blood pressure in the community of the Siliwangi Community Health Center were $p=0,02(a \leq 0,05)$ which means that there is a closeness between the relationship between physical activity of exercise and blood pressure in people with hypertension in the Muara Sanding Village of the Siliwangi Community Health Center. The analysis also found a negative correlation that was proven by the correlation coefficient value of -0.427 , which means that the more frequent the exercise, the lower the blood pressure. Based on the results of the study of respondents who lacked exercise and controlled blood pressure, there were four respondents, and exercise was lacking, but blood pressure was uncontrolled; there were 15 respondents. Respondents those with adequate exercise and blood pressure were controlled; there were eight respondents, and their blood pressure was uncontrolled; there were nine respondents. Respondent those exercise is good, and the blood pressure has controlled. There are 11 respondents, and the exercise is good, and the blood pressure is uncontrolled. There are four respondents. It means the respondents who exercise $>30$ minutes and 3x / mg; there are 11 respondents who have controlled blood pressure, the more exercise decreases blood pressure. This is in line with the results of research Librianti (2016) respondents of sports hypertension sufferers $<3$ times/week, as well as the results of the study, Rahma (2011) elderly who exercise 1-3 times/week have a risk for hypertension 3,820 times greater than elderly who exercise $>3$ times/week. According to (Bompa, 1994), blood pressure can bring down by doing moderateintensity aerobic exercise, walking fast.

Previous studies conducted by Khomarun, et al. (2014), in their study it was found that there were significant changes in changes in the decrease in systolic blood pressure in the respondents after 40 morning walks in 8 weeks, half-hour aerobics/day can reduce the risk of hypertension 19-30\%. People who are lazy to exercise usually have excess weight. As a result of excess weight, the blood volume will increase as well, resulting in an impact on the heart to pump blood and increasing the heavy burden of the heart's work in pumping blood to flow throughout the body so that peripheral pressure and cardiac output can increase and cause hypertension. According to Syatria (2006), aerobic activity is beneficial in improving and maintaining the health and endurance of the heart, lungs, blood circulation, muscles, and joints. According to Giam (2000), aerobic exercise stimulates muscles to work.

Many factors influence rising blood pressure, such as stress, poor diet, and obesity (Dalimartha, 2008). While according to Muhammadun (2010), factors that influence the increase in blood pressure include gender, age, family history, smoking habits, and lifestyle.

Benefits of regular exercise activities such as walking, swimming, cycling can trigger the smooth muscle of the heart to be strong so that at the time of contraction and throbbing strong and regular can increase endurance, facilitate breathing, eliminate disturbances of insomnia, reduce depression and anxiety, reduce osteoporosis, and stabilize body weight. According to Anies (2007), cholesterol deposits in arteries will disappear when exercising routinely and measurably. Based on the results of research on the aerobic exercise conducted by respondents, it takes 30 minutes - 45 minutes, done $1 \mathrm{x} /$ week. According to the results research, should be a routine exercise and carried out at least three 
times/week the respondents did routine exercise 1 time /week, but the respondents almost $67 \%$ of respondents worked in several fields which physically needed energy.

\section{Conclusions}

Exercise can affect a decrease in blood pressure if done routinely. There needs to be integration between non-communicable disease service programs and preventive activities in the community Nurses can improve health education about the importance of exercise and physical activity in hypertensive patients. Subsequent research was done by linking external factors that affect blood pressure in patients such as family support, the environment, and others.

Conflicts of Interest: No conflict of interest.

\section{References}

Ardiansyah, M. (2012). Medikal Bedah. Yogyakarta: DIVA Press.

Atun, T., Siswati., Kurdanti, W. (2014). Asupan Sumber natrium, rasio kalium, aktivitas fisik dan Tekanan Darah Pasien Hipertensi. Yogyakarta : Politeknik Kemenkes Yogyakarta

Bompa TO. (1994). Theory and Methodology of Training The Key to Athletic Performance. 2nd Edition, Iowa: Kendall/Hunt Publishing Company.

Budiono. 2015. Hubungan antara Aktivitas Fisik dengan Astatus Kesehatan Hipertensi pada Lanjut Usia di Desa Ngabean Kecamatan Mirit Kabupaten Kebumen. Undergraduate Thesis, Program Studi S1 Keperawatan, Sekolah Tinggi Ilmu Kesehatan Muhammadiyah Gombong.

Cartee, G. D., Hepple, R. T., Bamman, M. M., \& Zierath, J. R. (2016). Exercise Promotes Healthy Aging of Skeletal Muscle. Cell metabolism, 23(6), 1034-1047. doi:10.1016/j.cmet.2016.05.007

Dalimartha, S et al.. (2008) .Care Your Self Hipertensi. Penebar Plus Depok.

Gaesser, G (2012) (Direktur Healthy lifestyles Research Center Arizona State University. Pengaruh latihan jalan kaki 30 menit terhadap penurunan tekanan darah pada pasien penderita hipertensi di rumah sakit umum Kabanjahe.

Giam, CK. (2000). Ilmu Kedokteran Olahraga. Jakarta: Binarupa Aksara.

Hasanudin. (2018). hubungan aktivitas fisik dengan tekanan darah pada masyarakat penderita hipertensi di wilayah tlogosuryo kelurahan tlogomas kecamatan lowokwaru kota Malang. Nursing News, Volume 3 Nomor 1,2018.

Khomarun, M. et al. (2014). Pengaruh aktivitas fisik jalan pagi terhadap penurunan tekanan darah pada lansia dengan hipertensi stadium I di Posyandu Lansia Desa Makam Haji.Jurnal Terpadu Ilmu Kesehatan. Volume 3, No 2, November 2014.

Levine BD. 2001 Exercise physiology for the clinician. In exercise and sports cardiology.

Librianti, P. (2016). Analisis Hubungan antara kebiasaan olah raga dengan kejadian Hipertensi pada Pasien usia 45 tahun ke atas. Unair Published online.

Marliani, L \& Tantan, H. (2007). 100 Question \& Answer Hipertensi, Jakarta: PT Elex Media Kompuntindo Kelompok Gramedia.

Rahma, M. (2011). Risiko Kejadian Hipertensi pada Lansia Berdasarkan Pola Hidup di Puskesmas Mulyorejo Kota Surabaya. Skripsi. Surabaya:Universitas Airlangga.

Triyanto, E. (2014). Pelayanan Keperawatan Bagi Penderita Hipertensi Secara Terpadu. Yogyakarta: Graha Ilmu.

United States Departemen of Health and Human Services (USDHHS). (2004).The DASH eating plan. Washington: United States Departemen of Health and Human Services. 